Studia nad Autorytaryzmem i Totalitaryzmem 43, nr 3

Wrocław 2021

https://doi.org/10.19195/2300-7249.43.3.25

\author{
ALEKSANDRA MOROSKA-BONKIEWICZ \\ ORCID: 0000-0001-6192-3739 \\ Uniwersytet Wrocławski \\ aleksandra.moroska-bonkiewicz@uwr.edu.pl
}

\title{
Kształtowanie instrumentów ochrony demokracji w Polsce na przykładzie zakazu zgromadzeń. Perspektywa ideowa*
}

Słowa kluczowe: ochrona demokracji, zakaz zgromadzeń, treści nienawistne, demokracja walcząca, demokracja proceduralna, perspektywa ideowa.

\author{
SHAPING INSTRUMENTS OF DEMOCRACY PROTECTION IN POLAND \\ ON THE EXAMPLE OF THE ASSEMBLY BAN: IDEATIONAL PERSPECTIVE
}

\begin{abstract}
There is no single, universal model for the protection of democracy that sets limits on freedom and tolerance in liberal democracies. In response to political extremism, states apply various measures - from highly repressive ones, such as restrictions on freedom of speech or association, to more liberal ones based on persuasive strategies. Which instruments are adopted and implemented depends on the decisions of public actors. This article deals with the ban on assembly, which is a repressive instrument of democracy protection. Basing on the analysis of selected assembly bans cases, the aim is first to determine which model of democracy protection is closer to the solutions adopted in Poland - militant or procedural democracy, and second to indicate why such solutions were adopted. More precisely, by means of an ideational perspective, the aim is to explain the different positions taken by public actors in the process of implementing the assembly ban. The article uses the method of qualitative content analysis of legal acts and decisions made by public authorities regarding holding assemblies. By means of a purposeful case selection, the analysis was carried out on the assembly bans against extreme right-wing groups in Warsaw and Wrocław. The research has shown that the legal norms adopted in Poland allow the application of assembly bans in accordance with the concept of militant democracy. However, the implementation shows a different approach

* Artykuł powstał w wyniku realizacji projektu badawczego UMO-2014/15/D/HS5/03272 finansowanego ze środków Narodowego Centrum Nauki. Wyrazy podziękowania kieruję do recenzentów za bardzo wnikliwe i inspirujące komentarze.
\end{abstract}


of public actors in this matter. Municipalities are closer to the model of a militant democracy, as they allow a preventive ban on assembly as an instrument of public order protection in relation to freedom of speech infringements. In doing so, they do not maintain neutrality towards the views public discourse participants. The courts, on the other hand, exclude the subject of assemblies as a basis for their preventive restriction, the premises of the ban being violence or a direct threat to life, health and property. Their position is thus closer to the procedural model of protecting democracy. The adopted ideational perspective points to possible reasons for the different positions of public actors. Their attitude to values which are crucial for the protection of democracy shows differences. This applies, among others, to the different weight ascribed to particular democratic values, the different perception of threats to the society and the democratic state, and the divergence in defining the thresholds of freedom and tolerance.

Keywords: protection of democracy, assembly ban, hate speech, militant democracy, procedural democracy, ideational perspective.

\section{Wstęp}

Problematyka ochrony demokracji nabrała szczególnego znaczenia w okresie międzywojennym, gdy $\mathrm{z}$ jednej strony demokracja stała się standardem w wielu państwach europejskich, a $\mathrm{z}$ drugiej jej normy i wartości nie były w pełni akceptowane. Sprzyjało to rozwojowi ideologii i organizacji wrogich demokracji, co w efekcie spowodowało upadek systemu w wielu państwach. Stąd też w XX wieku przedmiotem dociekań teorii polityki i prawa stała się nie tylko istota demokracji, ale także to, jak prawo i polityka mogą aktywnie chronić system przed jego wrogami ${ }^{1}$. Pojęcie ,ochrona demokracji” obejmuje więc formy $\mathrm{i}$ instrumenty zabezpieczenia podstawowych wartości, mechanizmów i instytucji demokratycznych. W obliczu rozwoju skrajnie prawicowych ideologii i organizacji w ostatnich dekadach wciąż aktualny jest dylemat wskazywany między innymi przez Karla Poppera, jak stawić opór tym, którzy pośrednio lub wprost podważają wartości i zasady demokracji liberalnych, aby w procesie obrony, paradoksalnie nie ulec samozniszczeniu².

Ochrona demokracji jest szczególnie wrażliwą kwestią w tak zwanych społeczeństwach tranzycyjnych, które doświadczyły autorytaryzmów ${ }^{3}$. Wieloletnie ograniczenia praw i wolności tworzą potrzebę liberalnego podejścia do ochrony demokracji. Jednocześnie doświadczenia międzywojenne pokazują, że totalitaryzmy nierzadko przejmują władzę za pomocą emocjonalizmu, manipulacji opinią publiczną między innymi przez ksenofobiczną retorykę i demonizację

${ }^{1}$ O. Pfersmann, Shaping militant democracy, [w:] Militant Democracy, red. A. Sajó, Utrecht 2004, s. 48.

2 K. Popper, Offene Gesellschaft und ihre Feinde, t. 1. Der Zauber Platons, Tübingen 1992, s. 148

${ }^{3}$ U. Belavusau, Hate speech and constitutional democracy in Eastern Europe: Transitional and militant? (Czech Republic, Hungary and Poland), „Izraeli Law Review” 47, 2014, nr 1. 
mniejszości. Demokracja do przetrwania wymaga więc mocnych prodemokratycznych przekonań oraz mechanizmów chroniących zwłaszcza młody i słaby system. W Polsce masowe marsze środowisk skrajnie prawicowych przybrały na sile w drugiej dekadzie XXI wieku. Towarzyszące im niepokoje oraz język nienawiści wzbudzają kontrowersje wśród opinii publicznej. Tego typu zgromadzenia stawiają przed instytucjami państwa pytania o to: ile wolności należy przyznać tym, którzy promują postawy sprzeczne z ideami demokracji liberalnych?, czy i kiedy państwo demokratyczne ma prawo ograniczać wolności obywatelskie i polityczne?, jakie wartości powinno bezwzględnie chronić oraz przed jakimi zagrożeniami?

Nie istnieje jeden uniwersalny model ochrony wyznaczający limity wolności i tolerancji. Liberalne demokracje stosują różne środki w odpowiedzi na ekstremizm polityczny — od wysoce represyjnych, jak zakazy zrzeszania się, penalizacja obraźliwych wypowiedzi, po bardziej liberalne, oparte na strategiach włączających czy perswazyjnych ${ }^{4}$. To, jakie unormowania są przyjęte i jak są implementowane w danym państwie, zależy od decyzji aktorów publicznych. Ograniczenie praw i wolności w celu ochrony demokracji wymaga w demokracjach konstytucyjnych szczególnej legitymacji i jest z reguły powiązane ze ścisłą regulacją prawnoproceduralną. Odzwierciedlają one w pewnym stopniu rozumienie przez decydentów idei wolności i bezpieczeństwa w demokratycznym państwie konstytucyjnym ${ }^{5}$.

Niniejszy artykuł dotyczy jednego aspektu problematyki ochrony demokracji, a mianowicie zakazu zgromadzeń, który jest instrumentem wysoce represyjnym. Na podstawie analizy wybranych przypadków zakazów marszów i demonstracji środowisk skrajnie prawicowych celem jest, po pierwsze, wskazanie, w odniesieniu do toczącej się debaty teoretycznej, któremu modelowi ochrony demokracji bliższe są rozwiązania przyjęte w Polsce w badanym aspekcie - demokracji walczącej czy proceduralnej. Po drugie, wskazanie, dlaczego w procesie implementacji przyjęto takie rozwiązania, a nie inne. Ściślej, za pomocą perspektywy ideowej, celem jest wyjaśnienie odmiennych stanowisk przyjętych przez aktorów publicznych wobec zakazu zgromadzeń ugrupowań skrajnie prawicowych. Uwaga skupiona będzie na stosunku aktorów publicznych do kategorii istotnych z punktu widzenia ochrony demokracji - idei wolności i jej granic, percepcji zagrożeń społeczeństw i państw demokratycznych oraz koncepcji i oczekiwań w zakresie bezpieczeństwa.

Aby zrealizować przedstawione cele, stosuję metodę jakościowej analizy treści regulacji prawnych dotyczących zakazu zgromadzeń oraz decyzji i uzasadnień władz publicznych, które zgodnie z ustawami Prawo o zgromadzeniach mają kompetencje do decydowania w kwestiach odbywania zgromadzeń. Są to decyzje organów gminy (prezydentów miast), wojewodów jako organu

4 G. Capoccia, Defending Democracy. Reactions to Extremism in Interwar Europe, Baltimore 2005; W.M. Downs, Political Extremism in Democracies. Combating Intolerance, New York 2012.

${ }^{5} \mathrm{U}$. Backes, Limits of political freedom in democratic constitutional states - A comparative study of Germany, France and USA, „Totalitarismus und Demokratie” 3, 2006, s. 266. 
odwoławczego pierwszej instancji oraz sądów jako organu odwoławczego drugiej instancji (zgodnie z ustawą Prawo o zgromadzeniach z 1990 roku). Według nowej ustawy z 2015 roku sądy okręgowe przejęły rolę organu odwoławczego w pierwszej instancji. Zgodnie z formą właściwą do badań eksploracyjnych dokonałam celowego doboru przypadków zakazów zgromadzeń ${ }^{6}$. Realizacja postawionych w pracy celów wymaga analizy szczególnie tych przypadków, w których jako podstawę zakazu wskazano sprzeczność celów zgromadzenia lub jego odbycia z przepisami prawa karnego, a dokładnie tak zwane treści nienawistne stypizowane w kodeksie karnym w art. 256 i 257. Są to zakaz zgromadzenia wydany w Warszawie w 2015 roku oraz we Wrocławiu w 2018 roku. Dodatkowym przypadkiem ujętym w analizie jest zakaz zgromadzenia wydany w Warszawie w 2018 roku, w którym wskazana przesłanka nie była formalną podstawą zakazu, niemniej organ gminy w uzasadnieniu oparł się na argumentacji związanej z problematyką przestępstw określanych jako tak zwana mowa nienawiści. Zgodnie z informacją uzyskaną w Biurze Bezpieczeństwa i Zarządzania Kryzysowego w Warszawie zakaz w 2015 roku był pierwszym wydanym na podstawie wskazanej przesłanki. Natomiast zakazy w 2018 roku miały doniosłe znaczenie społeczno-polityczne, albowiem dotyczyły zgromadzeń zaplanowanych na 11 listopada 2018 roku, czyli w setną rocznicę odzyskania przez Polskę Niepodległości. W związku z tym organy władz publicznych wydały obszerne uzasadnienia swoich decyzji, co pozwala na przeprowadzenie dogłębnej analizy stanowisk.

W pierwszej części artykułu przedstawię debatę teoretycznoprawną dotyczącą instrumentów i modeli ochrony demokracji, wskazując na jej dwa typy idealne, tak zwaną demokrację walczącą oraz proceduralną. Pozwoli to na zdefiniowanie specyfiki regulacji prawnych i praktyki ich stosowania w Polsce. W kolejnej części omówię perspektywę ideową, jedną z perspektyw teoretycznych, która w wiarygodny sposób wyjaśnia decyzje aktorów publicznych, i wskażę, dlaczego jest ona istotna z punktu widzenia polityki ochrony demokracji ${ }^{7}$. W części empirycznej omówię unormowania ustawowe dotyczące zakazu zgromadzeń w kontekście przedstawionych modeli ochrony demokracji. Następnie dokonam analizy stanowisk i uzasadnień poszczególnych organów władzy ze szczególnym wskazaniem na wskazane kwestie ideowe. W ostatniej części sformułuję wnioski w odniesieniu do celów i pytań postawionych we wstępie.

${ }^{6}$ K. Krippendorff, Content Analysis, Los Angeles 2013, s. 24.

7 Inne to perspektywa władzy i interesów (rezultat polityczny jest efektem konfliktu między aktorami, nastawionymi na maksymalizację zysków), perspektywa problemu społecznego (decyzje nastawione są na rozwiązania jako efekt współpracy grup aktorów), perspektywa instytucjonalna (struktury polityczne — zasady konstytucyjne, prawne, biurokratyczne oraz dziedzictwo historyczne kształtują proces polityczny), E. Bleich, Race Politics in Britain and France. Ideas and Policymaking since the 1960s, Cambridge, 2003, s. 17-25. 


\section{Koncepcje ochrony demokracji - substancjalna versus proceduralna}

Punktem wyjścia współczesnych rozważań dotyczących ochrony demokracji stała się koncepcja demokracji walczącej, która w zasadniczy sposób wpłynęła na sposób postrzegania i klasyfikacje dostępnych instrumentów ${ }^{8}$. Pojęcie ukuł niemiecki filozof, politolog i prawnik Karl Löwenstein w latach trzydziestych XX wieku, po upadku demokracji weimarskiej i przejęciu władzy przez Hitlera. Na podstawie doświadczeń systemów totalitarnych doszedł do przekonania, że relatywistyczna i proceduralna koncepcja demokracji Hansa Kelsena musi zostać przedefiniowana tak, aby państwa mogły chronić swoje instytucje przed wewnętrznymi atakami ${ }^{9}$. Wyszczególnił więc arsenał represyjnych i zapobiegawczych środków ograniczających wolności i prawa konieczne w jego przekonaniu do efektywnej obrony demokracji w sytuacji zagrożenia ${ }^{10}$. Koncepcja demokracji walczącej była następnie szeroko dyskutowana przez naukowców w XX i XXI wieku, wchodząc na stałe do nauk politycznych i prawnych ${ }^{11}$. W praktyce została zakotwiczona, choć $\mathrm{w}$ różnym stopniu, w wielu powojennych demokracjach, przede wszystkim europejskich $^{12}$. Paradygmatycznym przykładem jest Republika Federalna Niemiec, która po wojnie zaimplementowała gros instrumentów zaproponowanych przez Löwensteina do ustawy zasadniczej i prawa karnego.

Jak wskazuje Jan-Werner Müller, tradycyjnie demokracja walcząca rozumiana jest jako „idea systemu demokratycznego, który jest gotowy przyjąć prewencyjne, na pierwszy rzut oka nieliberalne środki, w celu uniemożliwienia tym, których celem jest obalenie demokracji środkami demokratycznymi, zniszczenie

8 Określenie „demokracja walcząca” jest tłumaczeniem przyjętym przez autorkę niniejszego artykułu angielskiego określenia „militant democracy”.

9 Zob. H. Kelsen, Verteigigung der Demokratie, [w:] H. Kelsen, Verteidigung der Demokratie. Abhandlungen zur Demokratietheorie, wyb. i red. M. Jestaedt, O. Lepsius, Tübingen 2006.

${ }^{10}$ Były to ograniczenia dotyczące działalności partii lub organizacji politycznych, między innymi zakaz wywrotowych organizacji, zakaz tworzenia paramilitarnych organizacji. Regulacje chroniące instytucje państwa, między innymi pozbawienie mandatu zwolenników partii ekstremistycznych, którzy popierają zmianę formy rządów za pomocą środków niezgodnych z prawem. Ograniczenia wolności słowa, przez między innymi penalizację zniesławienia instytucji politycznych, nawoływania do przemocy lub nienawiści wobec różnych grup społecznych. Przeciwdziałanie propagandzie faszystów służyć miały ograniczania prawa do zgromadzeń, ustawodawstwo przeciwko publicznemu wysławianiu przestępców politycznych. Jednym z najostrzejszych środków było utworzenie policji (politycznej) kontrolującej działania i ruchy antydemokratyczne i antykonstytucyjne, K. Löwenstein, Militant democracy and fundamental rights, II, „The American Political Science Review" 31, 1937, nr 4.

11 Przykładem H.G. Jaschke, Streitbare Demokratie und Innere Sicherheit. Grundlagen, Praxis und Kritik, Opladen 1991; J.W. Müller, Militant democracy, [w:] The Oxford Handbook of Comparative Constitutional Law, red. M. Rosenfeld, A. Sajò, Oxford 2012.

12 Zob. The 'Militant Democracy' Principle in Modern Democracies, red. M. Thiel, London 2009. 
reżimu demokratycznego"13. Innymi słowy, za Angelą Bourne: „są to prawnie autoryzowane, nadzwyczajne restrykcje określonych praw politycznych, [...] prewencyjnie marginalizujące tych, którzy działając $w$ ramach prawa, podważają instytucje demokracji liberalnej" ${ }^{14}$. Jak podkreśla Svetlana Tyulkina, w najszerszym ujęciu są to restrykcje praw związanych z uczestnictwem w dyskursie publicznym wobec konkretnych obywateli lub grup, organizacji, wykonywane przez instytucje państwa ${ }^{15}$.

Z punktu widzenia teorii demokracji implementacja instrumentów demokracji walczącej jest dyskusyjna, co prowadzi do formułowania jej pryncypialnej krytyki. Prawnoteoretyczna debata toczy się między zwolennikami instrumentów represyjnych jako formy obrony demokracji, sceptykami szukającymi liberalnych uzasadnień mniej drakońskich instrumentów i przeciwnikami wskazującymi na brak efektywności i demokratycznej oraz liberalnej legitymacji środków represyjnych ${ }^{16}$. Strony odwołują się przy tym do dwóch modeli teoretycznych demokracji — substancjalnej i proceduralnej ${ }^{17}$.

Demokracja walcząca odzwierciedla substancjalne podejście do demokracji. W tym ujęciu demokracja poza zasadą większości opiera się na fundamentalnych wartościach i prawach, dlatego nie jest neutralna ideowo. Niesie więc element normatywny dotyczący tego, kto jest wrogiem demokracji, czyje prawa mają być chronione $^{18}$. Ochrona wartości, jak na przykład poszanowanie indywidualności, wolności, staje się uzasadnieniem ograniczeń wolności zrzeszania, słowa, zgromadzeń wobec przeciwników demokracji. Naukowcy w dużej mierze zgadzają się, że ograniczenia praw podstawowych w obronie demokracji są kompatybilne z zasadami liberalnych demokracji konstytucyjnych ${ }^{19}$. Uzasadniają je wyjątkowymi i ściśle określonymi sytuacjami, w których instrumenty są stosowane, ich krótkotrwałością oraz ich zdolnością do szybkiego i efektywnego ograniczania przeciwników demokracjii ${ }^{20}$. Bardziej ostrożni zwolennicy starają się doprecyzować zakres i uwarunkowania stosowania środków represyjnych. Są oni świadomi,

13 J.W. Müller, op. cit., s. 1253.

14 A. Bourne, Beyond Militant Democracy: Mapping Initiatives Opposing Populist Parties, manuskrypt, s. 1.

15 S. Tyulkina, Militant Democracy. Undemocratic Political Parties and Beyond, London-New York 2015, s. 14, 46-47.

16 A. Malkopoulou, Introduction. Militant democracy and its critics, [w:] Militant Democracy and Its Critics. Populism, Parties, Extremism, red. A. Malkopoulou, A.S. Kirshner, Edinburgh 2019, s. $1-2$.

17 G. Capoccia, op. cit., s. 216; B. Rijpkema, Militant Democracy. The Limits of Democratic Tolerance, New York 2018, s. 333.

18 G.H. Fox, G. Nolte, Intolerant Democracies, „Harvard International Law Journal” 36, 1995, nr 1; B. Rijpkema, op. cit.

19 G. Capoccia, Militant democracy: The institutional bases of democratic self-preservation, „Annual Review of Law and Social Science” 9, 2013, s. 219.

${ }^{20}$ A. Malkopoulou, L. Norman, Three models of democratic self-defence: Militant democracy and its alternatives, „Political Studies” 66, 2018, nr 2, s. 446. 
że wszelkie ograniczenia uczestnictwa $\mathrm{w}$ procesach decyzyjnych dokonują się kosztem demokracji, stąd też konieczne jest ich limitowanie i uzasadnienie, inaczej demokracja traci na wartości ${ }^{21}$. Ważne jest więc precyzyjne zdefiniowanie przepisów prawnych i sposób ich stosowania w konkretnych przypadkach ${ }^{22}$.

Krytyka demokracji walczącej zasadza się w głównej mierze na podważaniu ogólnej legitymacji restrykcji praw i wolności obywatelskich w demokracjach liberalnych. Jak wskazują Carlo Invernizzi Accetti i Ian Zuckerman, wiąże się to z nieredukowalnym elementem arbitralności demokracji walczącej dotyczącym tego, kto powinien być uznany za wroga demokracji oraz kto ma być członkiem wspólnoty politycznej. W opinii autorów nie istnieje demokratyczny sposób określenia tego, kto jest wrogiem demokracji, albowiem jest to jednocześnie decyzja o granicach wspólnoty politycznej. Stąd też demokracja walcząca zawodzi jako prawomocny środek wykluczania i może skutkować arbitralnym potraktowaniem politycznych oponentów jako wrogów demokracji - istnieje więc ryzyko instrumentalizacji represji ${ }^{23}$. Inni wskazują, że demokracja walcząca za mało wagi przywiązuje do demokratycznego procesu politycznego. Ograniczając na podstawie poglądów dostęp do dyskusji różnym grupom społecznym, zaprzecza jej pierwotnej idei - rządu sprawowanego przez lud ${ }^{24}$.

Problematyczny jest także prewencyjny aspekt demokracji walczącej, który Eva Brems określa jako problem czasu ${ }^{25}$. Potrzeba interwencji za pomocą instrumentów demokracji walczącej wzrasta wraz z wzrostem poparcia dla antydemokratów, ale gdy antydemokratyczne poglądy cieszą się większym poparciem, demokratyczna legitymacja ingerencji maleje. Wczesne zastosowanie środków może sprawić, że będą one się wydawać nieproporcjonalne i niedemokratyczne. Ponieważ nie istnieją prawne kryteria wyboru właściwego momentu na interwencje, decyzja o zastosowaniu represyjnych instrumentów prewencyjnych może być postrzegana jako polityczna ${ }^{26}$. Wiąże się z tym kolejny dylemat: kto

21 Przykładowo, zdaniem A. Kirshnera wykluczenie powinno dotyczyć tylko tych aktorów, którzy naruszają prawo uczestnictwa innych osób lub grup w procesach demokratycznych, zob. idem, A Theory of Militant Democracy. The Ethics of Combating Extremism, New Haven 2014. Dla S. Rummensa i K. Abtsa uzasadnienie wykluczenia niedemokratycznych partii wzrasta, gdy zbliżają się one do władzy, zob. S. Rummens, K. Abts, Defending democracy: The concentric containment of political extremism, „Political Studies” 58, 2008, nr 4. Inni autorzy sugerują, że zakazy powinny dotyczyć jedynie antydemokratycznych działań, a nie idei, aby nie ograniczać wolności myśli; zob. A. Bourne, The proscription of parties and the problem with militant democracy, ,The Journal of Comparative Law" 7, 2012, nr 1, s. 209; G. Capoccia, Defending Democracy, s. 57.

22 O. Pfersmann, op. cit., s. 52.

23 I.C. Accetti, I. Zuckerman, What's wrong with militant democracy?, „Political Studies” 65 (IS), 2017, s. 188, 193-194.

24 B. Rijpkema, op. cit., s. 103-110.

25 E. Brems, State regulation of xenofobia versus individual freedoms: The European view, „Journal of Human Rights” 1, 2002, nr 4, za: B. Rijpkema, op. cit., s. 108-109.

26 B. Rijpkema, op. cit., s. 109. 
jest upoważniony do określania, kto i kiedy powinien być wykluczony z procesu deliberacji demokratycznej?

Krytycy demokracji walczącej odwołują się do idei demokracji proceduralnej, postrzeganej za Schumpeterem jako rozwiązanie instytucjonalne służące podejmowaniu decyzji, w którym jednostki decydują na wolnym rynku idei w drodze konkurencji - argumentacji i perswazji ${ }^{27}$. Jak wskazywał Hans Kelsen, główny przeciwnik koncepcji Löwensteina, podstawą demokracji jest wolność postrzegana jako autonomia jednostki, a jej fundamentalną zasadą jest to, że musi dopuszczać do uczestnictwa w procesach decyzyjnych, w równym stopniu, różne stanowiska polityczne, nawet te, które promują idee nieakceptowalne, antydemokratyczne i nieliberalne. Demokracja jest więc neutralna wobec prezentowanych idei i wartości. W rezultacie demokracja może zostać obalona, ale jeśli trwa wbrew woli większości, wówczas przestaje być demokracjąa ${ }^{28}$. Ochrona systemu zależy więc w głównej mierze od woli politycznej większości. Reakcje wobec wrogów demokracji opierają się na tolerancyjnym podejściu wobec różnorodnych pozycji ideowych oraz procedurach typowych dla prawa karnego. Najbliższe proceduralnej koncepcji ochrony demokracji są Stany Zjednoczone Ameryki. Orzecznictwo USA ukształtowało tak zwany rygorystyczny test, wymóg wykazania „,bezpośredniego niebezpieczeństwa wyrządzenia szkody" w sprawach dotyczących podstawowych wolności, co systemowo ogranicza możliwość ich restrykcji bez udowodnienia podżegania do czynu karalnego ${ }^{29}$.

\section{Idee jako czynnik decyzji aktorów publicznych}

Klarowna dychotomia między demokracją walczącą i proceduralną w praktyce nie znajduje odzwierciedlenia. Zdaniem Otto Pfersmanna demokracje są zawsze bardziej lub mniej walczące ${ }^{30}$. Istotne są przy tym zarówno zakotwiczone w konstytucji i prawie regulacje, jak i praktyka ich stosowania. Uwe Backes wskazuje, że specyfika i zakres przyjętych ograniczeń praw i wolności politycznych oraz ich implementacja odzwierciedlają rozumienie przez decydentów publicznych danego państwa idei wolności, percepcje współczesnych zagrożeń i oczekiwania w zakresie bezpieczeństwa, te natomiast zależne są od specyficznych doświadczeń historycznych. Przez porównanie powojennej koncepcji i praktyki ochrony demokracji w USA, Niemczech i Francji Backes pokazał, że idea wolności i bezpieczeństwa determinują i ograniczają się wzajemnie w specyficzny dla danego państwa sposób ${ }^{31}$. Podobnie William M. Downs, który podkreśla,

\footnotetext{
27 Ibidem, s. 103-110.

${ }^{28}$ H. Kelsen, op. cit., s. 62.

29 B. Rijpkema, op. cit., s. 104; A. Malkopoulou, L. Norman, op. cit., s. 448-449.

30 O. Pfersmann, op. cit., s. 52-53.

31 U. Backes, op. cit., s. 265-266.
} 
że tolerancja polityczna zależy od tego, czy postrzegasz kogoś lub coś jako zagrożenie. Wysoki poziom postrzeganego zagrożenia wpływa na bardziej represyjne środki i reakcje ${ }^{32}$. Przy czym rzeczywista waga danego zagrożenia nie musi być proporcjonalna do jego subiektywnej interpretacji ${ }^{33}$. Wskaźniki danego problemu podlegają zatem interpretacji. Twierdzenie, że idee są istotnym czynnikiem determinującym decyzje aktorów władzy publicznej, uzasadnił przekonująco Erik Bleich. W swoich badaniach wykazal, że idee w postaci ram interpretacyjnych najlepiej wyjaśniają odmienne polityki rasowe przyjęte w Wielkiej Brytanii i Francji. Oprócz czynników takich jak układ władzy i interesów czy specyficzna struktura instytucjonalna, zróżnicowane koncepcje rasy, rasizmu i antyrasizmu miały jego zdaniem największy wpływ na specyfikę polityki poszczególnych państw w badanym obszarze. Bleich wykazał jednocześnie, że ramy interpretacyjne nie są jednakowo podzielane przez wszystkich aktorów w danym państwie. Oznacza to, że równolegle występuje wiele różnych idei, które mogą wpływać na kształtowanie polityki ${ }^{34}$. Podobnie Bénédicte Laumond, która ukazuje różne interpretacje instrumentów reagowania wobec skrajnej prawicy przez aktorów władzy publicznej w jednym państwie ${ }^{35}$. W razie braku zgody między aktorami ostateczny rezultat zależy od tego, które interpretacje odgrywają większą rolę na danym etapie tworzenia rozwiązañ ${ }^{36}$. Stąd też $\mathrm{w}$ analizie procesu kształtowania polityki trzeba uwzględnić kwestie władzy ${ }^{37}$.

Perspektywa ideowa przyjęta $\mathrm{w}$ niniejszej publikacji koncentruje się więc na roli idei w kształtowaniu danej polityki państwa. Jak wskazuje Erik Bleich, pozwala ona na określenie celów i motywacji poszczególnych aktorów w procesie decyzyjnym, a także wyjaśnia, dlaczego aktorzy przyjmują odmienne rozwiązania w podobnym kontekście ${ }^{38}$. Podążając za Bleichem: wieloaspektowe mikroidee tworzą ramy interpretacyjne, na które składa się zestaw kognitywnych schematów, narzędzi językowych, przekonań o przyczynowości oraz normatywnej wrażliwości. Owe ramy interpretacyjne są wykorzystywane w celu konceptualizacji danej domeny polityki. Schematy kognitywne obejmują definicje, koncepcje, symbole, metafory i analogie. Mapy moralne są podstawą oceny, wartościowania zdarzeń, wskazując dobre i złe rozwiązania ${ }^{39}$. Ramy interpretacyjne pomagają aktorom zdefiniować cele i ustanawiać ich priorytety, określić problemy i zinterpretować wydarzenia, tym samym nakierowują aktorów na określone sądy przyczynowe

32 W.M. Downs, op. cit., s. 58.

33 J. van Donselaar, op. cit., s. 277.

34 E. Bleich, op. cit., s. 14.

35 B. Laumond, State Responses to the Radical Right in France and Germany: Public Actors, Policy Frames and Decision-Making, London 2020.

36 E. Bleich, op. cit., s. 185-186.

37 B. Laumond, op. cit., s. 26.

38 E. Bleich, op. cit., s. 13.

39 Ibidem, s. 28-29. 
i normatywne dotyczące efektywnej i stosownej polityki. W ten sposób wpływają na kierunki realizowanej polityki ${ }^{40}$.

Analiza ram interpretacyjnych przyjętych przez aktorów publicznych względem kategorii szczególnie istotnych z punktu widzenia ochrony demokracji wolności, zagrożeń demokracji oraz bezpieczeństwa pozwoli lepiej zrozumieć motywacje dotyczące implementacji zakazu zgromadzeń wobec środowisk skrajnie prawicowych. Niewątpliwie dla pełnego obrazu przyczyn przyjętych rozwiązań zasadne jest zestawienie ram interpretacyjnych z innymi czynnikami, w szczególności specyfiką poszczególnych instytucji oraz interesami aktorów publicznych. Wykracza to jednak poza cele przyjęte w niniejszej analizie.

\section{Unormowania prawne dotyczące zakazu zgromadzeń w Polsce}

Zgodnie z art. 57 Konstytucji RP z 1997 roku każdemu zapewnia się wolność organizowania pokojowych zgromadzeń i uczestniczenia w nich, a ograniczenia tej wolności może określać ustawa ${ }^{41}$. Wolność zgromadzeń nie ma jednak charakteru absolutnego. Artykuł 57 Konstytucji dopuszcza możliwość jej ograniczenia w drodze ustawy, natomiast ujęta w art. 31 ust. 3 Konstytucji RP ogólna klauzula ograniczeń w korzystaniu z wolności i praw człowieka określa przesłanki, a jednocześnie granice i wskazuje na konieczność zachowania przez ustawodawcę proporcji w ograniczeniach owych wolności ${ }^{42}$. Mogą one nastąpić, ,gdy są konieczne w demokratycznym państwie dla jego bezpieczeństwa lub porządku publicznego, bądź dla ochrony środowiska, zdrowia i moralności publicznej, albo wolności i praw innych osób" (art. 31 ust. 3 Konstytucji). Ograniczenia wolności zgromadzeń traktowane są więc w polskim ustawodawstwie jako wyjątek. Szczegółowe regulacje zawarte zostały w ustawach: Prawo o zgromadzeniach z 5 lipca 1990 roku $^{43}$,

40 Ibidem, s. 26-27.

41 Konstytucja Rzeczypospolitej Polskiej z dnia 2 kwietnia 1997 r., Dz.U. 1997 Nr 78, poz. 483 z późn. zm.

42 Wolność zgromadzeń w Polsce w latach 2016-2018. Raport Rzecznika Praw Obywatelskich, Warszawa 2017, s. 32.

43 Artykuł 8 ust. 1 ustawy z 1990 r. zawiera enumeratywnie wyliczone przesłanki wydania decyzji zakazującej zgromadzenia przez organ gminy, jeżeli cel lub odbycie zgromadzenia sprzeciwiają się omawianej ustawie lub naruszają przepisy ustaw karnych (pkt 1), odbycie zgromadzenia może zagrażać życiu lub zdrowiu ludzi albo mieniu w znacznych rozmiarach (pkt 2). Zgromadzenia wymagają uprzedniego zawiadomienia organu gminy, które powinno zawierać między innymi cel, program, dokładny czas i miejsce, ewentualnie trasę przejścia i liczbę uczestników, ustawa Prawo o zgromadzeniach z dnia 5 lipca 1990 r., http://prawo.sejm.gov.pl/isap.nsf/download.xsp/WDU 19900510297/U/D19900297Lj.pdf. 
w zastępującej ją ustawie z 24 lipca 2015 roku $^{44}$ oraz ustawie z dnia 7 maja 1999 roku o ochronie terenów byłych hitlerowskich obozów zagłady ${ }^{45}$.

Przesłanki wymienione w ustawach Prawo o zgromadzeniach wskazują, że podstawą zakazu zgromadzeń w Polsce jest nie tylko sytuacja, w której odbycie zgromadzenia narusza wolność pokojowego gromadzenia się, może zagrażać życiu, zdrowiu lub mieniu w znacznych rozmiarach, ale także gdy cel zgromadzenia lub jego odbycie są sprzeczne z obowiązującym prawem karnym. To rozszerzenie powoduje, że władze publiczne mogą wskazać jako podstawę zakazu na przykład treść zgromadzeń, która zdaniem organu władzy narusza przepisy karne ${ }^{46}$. Wówczas powody nałożenia zakazu tracą cechy neutralności, to znaczy niezależności od przedmiotu zgromadzenia. Podobne unormowania występują w Niemczech ${ }^{47}$. Do oceny wystąpienia owej przesłanki istotna jest treść zawiadomienia oraz zawarty w nim cel zgromadzenia lub zachowania uczestników przewidziane programem zgromadzenia ${ }^{48}$. Takie unormowanie prawne otwiera możliwość zastosowania zakazu zgromadzeń zgodnie z założeniami koncepcji demokracji walczącej, albowiem stwarza możliwość zapobiegawczego (prewencyjnego) i represyjnego reagowania wobec 'wrogów demokracji' działających pokojowo.

44 Artykuł 14 ustawy wskazuje trzy grupy przesłanek tworzących podstawę decyzji o zakazie. Pierwsza, gdy cel zgromadzenia narusza wolność pokojowego zgromadzania się, jego odbycie narusza art. 4 ustawy lub zasady organizowania zgromadzeń oraz gdy cel zgromadzenia lub jego odbycie naruszają przepisy karne. Przy czym art. 4 odmawia prawa organizowania zgromadzeń osobom niemającym pełni zdolności do czynności prawnych oraz, co wynika z istoty pokojowego charakteru zgromadzania się, osobom posiadającym broń, materiały wybuchowe, wyroby pirotechniczne lub inne niebezpieczne materiały lub narzędzia. Druga grupa przesłanek dotyczy sytuacji, gdy odbycie zgromadzenia stanowić może zagrożenie życia, zdrowia lub mienia w znacznych rozmiarach, w tym gdy zagrożenia tego nie udało się usunąć, gdy w tym samym miejscu i czasie, w szczególności w odległości mniejszej niż 100 metrów zgłoszone zostały dwa lub więcej zgromadzeń (art. 14 pkt 3 w zw. z art. 12 i 13). O pierwszeństwie wyboru miejsca i czasu zgromadzenia decyduje kolejność wniesienia zawiadomień. Nowelizacja z 2016 r. wprowadziła trzecią przesłankę — zakaz zgromadzeń, które mają się odbyć w miejscu i czasie, w których odbywają się zgromadzenia cykliczne; ustawa z dnia 24 lipca 2015 r. Prawo o zgromadzeniach, http://prawo.sejm.gov. pl/isap.nsf/download.xsp/WDU20150001485/U/D20151485Lj.pdf; Wolność zgromadzeń w Polsce w latach 2016-2018, s. 33.

45 Ustawa definiuje szczególne zasady zgromadzeń na obszarze Pomników Zagłady i ich stref ochronnych, wskazując, że odbycie takiego zgromadzenia wymaga zgody wojewody i może być także przez niego rozwiązane, Dz.U. z 1999 r. Nr 41, poz. 412.

46 Kwestia wadliwości konstrukcji prawnej zapisu nie jest przedmiotem analizy w niniejszym artykule, więcej na ten temat zob. S. Gajewski, A. Jakubowski, Prawo o zgromadzeniach. Komentarz, Warszawa 2017, s. 99-101.

47 Zob. J. van Donselaar, Patterns of response to the extreme right in Western Europe, [w:] Right-Wing Extremism in the Twenty-First Century, red. P.H. Merkl, L. Weinberg, London 2003, s. 266; G. Flümann, Streitbare Demokratie in Deutschland und den Vereinigten Staaten. Der staatliche Umgang mit nichtgewalttätigem politischem Extremismus im Vergleich, Wiesbaden 2015, s. 234-247.

48 A. Rzetecka-Gil, Prawo o zgromadzeniach. Komentarz, LEX 2019. 
Zgromadzenia, które w państwach demokratycznych co do zasady pełnią funkcję wentyla opinii i emocji społecznych powstałych wskutek prowadzonej polityki, związane są więc z innymi wolnościami i prawami w sferze publicznej, W szczególności z wolnością słowa ${ }^{49}$. W Polsce, podobnie jak w innych państwach demokratycznych, kontrowersje dotyczące zakazu zgromadzeń środowisk skrajnie prawicowych związane są w szczególności z przejawami tak zwanej mowy nienawiści ${ }^{50}$. Choć nie jest ona zdefiniowana $\mathrm{w}$ polskim prawie, to treści nienawistne penalizują art. 256 i 257 k.k. ${ }^{51}$

Zgodnie $\mathrm{z}$ uzasadnieniem prawodawcy przedmiotem ochrony $\mathrm{z}$ art. 256 ust. 1 jest ,funkcjonowanie państwa w sposób demokratyczny, w ramach takiegoż ustroju, i zapewniający zarazem obywatelom i innym osobom zamieszkałym na jego terytorium ochronę ich praw" ${ }^{52}$. W praktyce zakaz zgromadzeń w związku z nadużyciem wolności słowa rodzi jednak liczne trudności i kontrowersje. Przykładowo, jak wskazuje Jakubowski, granica między krytyką polityki państwa wobec obcokrajowców i narastających w związku z tym emocji społecznych a nawoływaniem do nienawiści wobec określonych grup jest trudna do wskazania ${ }^{53}$. Jak wynika z orzecznictwa, art. 256 ust. 1 zawiera zwroty w pewnym stopniu niedookreślone i nieostre, jak „nawołuje do nienawiści”, a są uściślone w wyniku kontekstu normatywnego, w którym występują ${ }^{54}$. Ponadto, jak wskazuje Jakubowski:

nie każda sytuacja potencjalnego naruszenia przepisów karnych uzasadnia zakaz zgromadzeń. [...] Wykluczenie z góry poglądów uznanych przez władze za mogące wzbudzać negatywne odczucia wobec pewnych grup ludzi może bowiem wywołać efekt mrożący dla debaty pu-

49 Wolność zgromadzeń w Polsce w latach 2016-2018, s. 8.

50 Zgodnie z rekomendacjami Komitetu Ministrów Rady Europy nr R97/20 mowa nienawiści obejmuje wszelkie formy wypowiedzi, które szerzą, propagują czy usprawiedliwiają nienawiść rasową, ksenofobię, antysemityzm oraz inne formy nienawiści oparte na nietolerancji, między innymi: nietolerancję wyrażającą się w agresywnym nacjonalizmie i etnocentryzmie, dyskryminację i wrogość wobec mniejszości, imigrantów i ludzi o imigranckim pochodzeniu.

51 Art. 256 ust. 1 stanowi: „Kto publicznie propaguje faszystowski lub inny totalitarny ustrój państwa lub nawołuje do nienawiści na tle różnic narodowościowych, etnicznych, rasowych, wyznaniowych albo ze względu na bezwyznaniowość, podlega grzywnie, karze ograniczenia wolności albo pozbawienia wolności do lat 2”. Natomiast art. 257: „Kto publicznie znieważa grupę ludności albo poszczególną osobę z powodu jej przynależności narodowej, etnicznej, rasowej, wyznaniowej albo z powodu jej bezwyznaniowości lub z takich powodów narusza nietykalność cielesną innej osoby, podlega karze pozbawienia wolności do lat 3". Zob. ustawa z dnia 6 czerwca $1997 \mathrm{r}$. Kodeks karny, s. 80, 95-96, http://prawo.sejm.gov.pl/isap.nsf/download.xsp/WDU19970880553/U/ D19970553Lj.pdf.

52 Sejm VI kadencji, druk nr 1288.

53 S. Gajewski, A. Jakubowski, op. cit., s. 108-109.

54 Zgodnie $\mathrm{z}$ orzecznictwem, jeśli art. 256 ust. 1 miałby stanowić podstawę zakazu zgromadzeń, to dla jego zastosowania organ musi wykazać, że organizator umyślnie kieruje się zamiarem bezpośrednim nawoływania do nienawiści na tle określonych różnic międzyludzkich, ibidem, s. 110. 
blicznej oraz niepewność czy dane poglądy mieszczą się jeszcze w dopuszczalnym zakresie, czy już nie ${ }^{55}$.

Inne stanowisko prezentują A. Gliszczyńska-Grabias oraz L. Wiśniewski, którzy podkreślają, że zgromadzenia, podczas których formułowane są treści nienawistne, na przykład rasistowskie, nawet bez przejawów fizycznej przemocy, mogą u określonej grupy powodować odczucie fizycznego zagrożenia. Tracą wówczas charakter pokojowy ${ }^{56}$.

W obliczu zasygnalizowanych problemów i zróżnicowanych opinii dotyczących zakazu zgromadzeń kluczowy w wyznaczeniu granic wolności jest sposób jego implementacji. Proces kształtowania wolności zgromadzeń w Polsce przybrał na intensywności po serii zakazów Parady Równości — w Warszawie w 2004 roku oraz w Poznaniu w 2005 roku. Zakazy te uruchomily nie tylko dyskusję publiczną na temat praw i wolności konstytucyjnych, lecz także skutkowały istotnymi orzeczeniami Trybunału Konstytucyjnego, Naczelnego Sądu Administracyjnego, Sądu Najwyższego oraz sądów administracyjnych, które w wielu aspektach określiły możliwości i granice zastosowania zakazu zgromadzeńn ${ }^{57}$. Wskazane wyroki mają istotne znaczenie w kontekście analizowanej w niniejszym artykule problematyki ochrony demokracji, co zostanie zaprezentowane w kolejnej części artykułu, w analizie decyzji sądów, wojewodów i gmin w kwestii zakazu zgromadzeń środowisk skrajnie prawicowych.

\section{Implementacja zakazu zgromadzeń wobec środowisk skrajnie prawicowych}

Dalej przedstawione zostaną decyzje władz publicznych w wybranych przypadkach zakazów zgromadzeń wydanych wobec środowisk skrajnie prawicowych w Polsce. Celem tej części artykułu jest zdefiniowanie stanowisk poszczególnych aktorów w kwestii możliwości zakazu zgromadzenia na podstawie przesłanki związanej z nadużyciem wolności słowa, a także wskazanie, czym aktorzy motywują przyjęte pozycje. Szczególna uwaga skupiona będzie na tym, jak aktorzy rozumieją wartości demokratyczne, w tym idę̨ wolności, i jak definiują jej granice, jak postrzegają zagrożenia społeczeństw i państw demokratycznych oraz jakie mają podejście i oczekiwania względem bezpieczeństwa.

55 Ibidem, s. 109.

56 Ibidem, s. 106.

57 A. Bodnar, Shaping the freedom of asembly: Counter-productive effects of the Polish road towards illiberal democracy, [w:] Free to Protest: Constituent Power and Street Demonstration, red. A. Sajo, Utrecht 2009. 


\section{Zakaz wydany przez organ gminy miasta stołecznego Warszawy w dniu 8 września 2015 roku}

Zakaz wydany przez Prezydent Warszawy dotyczył zgromadzenia „Polacy przeciwko imigrantom". Celem zgromadzenia podanym w zgłoszeniu było „pokazanie sprzeciwu wobec muzułmańskich imigrantów oraz przypomnienie i uczczenie wiktorii wiedeńskiej" 58 . Zakaz organu gminy oparty był na przesłankach zawartych w art. 8 ust. 1 pkt 1 i 2 ustawie Prawo o zgromadzeniach z 1990 roku, czyli sytuacji, w której cel lub jego odbycie sprzeciwiają się owej ustawie lub naruszają przepisy ustaw karnych, a także odbycie zgromadzenia może zagrażać życiu, zdrowiu ludzi lub mieniu w znacznych rozmiarach.

W opinii organu gminy cel nie budził zastrzeżeń, niemniej na podstawie zamieszczanych informacji na portalach społecznościowych, w tym wizerunku oficjalnego plakatu manifestacji działanie organizatora mogło wyczerpywać znamiona czynów zabronionych określonych w art. 216, 256 i 257 k.k. ${ }^{59}$ Organ gminy w uzasadnieniu powołał się na orzecznictwo i doktrynę prawa karnego, wskazując między innymi, że dobrem prawnym jest cześć i nietykalność cielesna człowieka, rozpatrywana szczególnie „w odniesieniu do funkcjonowania całego porządku publicznego, którego filarem jest pluralizm oraz respektowanie podstawowych praw i wolności innych osób, a przez to zwalczanie wszelkich form prześladowań, nietolerancji i wykluczenia społecznego" ${ }^{60}$. Ponadto, odwołując się do art. 32 ust. 2 Konstytucji RP, Prezydent Warszawy wyraziła przekonanie, że prawnokarna ochrona przed tak zwanymi przestępstwami z nienawiści stanowi jeden z elementów antydyskryminacyjnej polityki państwa demokratycznego, a także wrogość na tle rasowym, wyznaniowym czy narodowościowym jest źródłem poważnych napięć społecznych i stoi w sprzeczności z porządkiem publicznym ${ }^{61}$.

Druga przesłanka zakazu związana była z miejscem i trasą manifestacji kolidującą z wcześniej zgłoszonymi imprezami. W opinii organu gminy, ze względu na konieczność zapewnienia bezpieczeństwa i porządku publicznego oraz zdrowia uczestników imprez, przejście zgłoszonego zgromadzenia trasą wskazaną w zawiadomieniu jest niemożliwe ${ }^{62}$.

Organizator odwołał się od niniejszej decyzji do Wojewody Mazowieckiego. W odwołaniu wskazał między innymi na brak materiału dowodowego, że przebieg zgromadzenia będzie naruszał przywołane przepisy kodeksu karnego, brak

58 Decyzja Prezydenta Miasta Warszawy z dnia 8 września 2015 r., nr WV/5310/ZG/8/2015.

59 Treść artykułów 256 i 257 zob. przypis 53. Artykuł 216 k.k. penalizuje czyny określone jako zniewaga innych osób w jej obecności, lub pod jej nieobecność, lecz publicznie lub w zamiarze, aby zniewaga do tej osoby dotarła, a także zniewagę osób za pomocą środków masowego komunikowania. Ustawa z dnia 6 czerwca 1997 r. Kodeks karny, s. 80, 95-96, http://prawo.sejm. gov.pl/isap.nsf/download.xsp/WDU19970880553/U/D19970553Lj.pdf.

60 Decyzja Prezydenta Miasta Warszawy z 8 września 2015 r., s. 3.

61 Ibidem.

62 Ibidem, s. 3-4. 
wyjaśnień, w jaki sposób zgromadzenie mogłoby zagrażać życiu, zdrowiu lub mieniu, brak wezwania organizatora do zmiany czasu lub miejsca zgromadzenia. Wskazał także na pozaprawne motywy podjęcia decyzji zawarte w wypowiedziach wiceprezydenta m.st. Warszawy. Według organizatora wiceprezydent powoływał się na zagrożenia mową nienawiści, która w polskim prawie nie jest skwalifikowanym przestępstwem ${ }^{63}$.

Wojewoda przychylił się do argumentacji organizatora zgromadzenia, wskazując, że organ gminy „dopuścił się w stopniu rażącym naruszenia przepisów kodeksu postępowania administracyjnego, a naruszenie to miało istotny wpływ na wynik sprawy"64. Uzasadnienie decyzji powinno bowiem zawierać fakty i dowody jako podstawa decyzji, czego organ gminy nie wykazał. W opinii Wojewody przepisy te są proceduralną gwarancją prawidłowości oceny dopuszczalności ograniczenia wolności zgromadzeń, a ich nieprzestrzeganie prowadzi do ograniczenia samej wolności przez władzę publiczną, która ma zagwarantować swobodę z niej korzystania. Wojewoda uznał między innymi, że organ gminy w sposób dowolny i arbitralny utożsamiał wulgarne i ksenofobiczne wypowiedzi oraz wizerunki zamieszczone na portalu społecznościowym Facebook organizatora czy też plakaty i posty użytkowników Facebooka z poglądami organizatora zgromadzenia oraz z celem odbycia zgromadzenia i nie zażądał od organizatora wyjaśnień w tej kwestii. Ponadto, w opinii Wojewody, organ gminy nie wskazał, jakie elementy konkretnego stanu faktycznego są podstawą do wnioskowania, że przebieg zgromadzenia będzie naruszał art. 216, 256 i 257 k.k., stąd też naruszył między innymi przepisy art. $107 \S 3$ k.p.a. ${ }^{65}$ Wojewoda jednocześnie zdefiniował wolność zgromadzeń jako prawo do organizowania zgromadzenia publicznego i manifestowania poglądów w kwestiach politycznych i społecznych: „nie ma przy tym znaczenia, jaka jest treść tych poglądów oraz czy są one zbieżne z poglądami osób sprawujących funkcje publiczne" 66 . Wskazał także, że napływ imigrantów do Europy może mieć doniosłe konsekwencje polityczne, gospodarcze i społeczne, ,dlatego też w realiach demokratycznego państwa prawa, jakim jest Rzeczpospolita Polska, jest godnym tematem publicznej dyskusji z [...] uwzględnieniem zasady pluralizmu poglądów [...]"67. Wojewoda skierował sprawę do ponownego rozpatrzenia przez organ gminy, wskazując na konieczność uzupełnienia materiału dowodowego sprawy i podjęcie próby uzgodnienia zmodyfikowanej trasy przemarszu $^{68}$.

\footnotetext{
63 Decyzja Wojewody Mazowieckiego z 10 września 2015 r., WBZK-I.6110.22.2015.

64 Ibidem, s. 3. Wojewoda wskazał na art. 6, 7, 10 § 1, art. 77 § 1, art. 80, 107 § 3 k.p.a.

65 Ibidem, s. 5.

66 Ibidem, s. 4.

67 Ibidem, s. 5.

68 Ibidem, s. 5-6.
} 


\section{Zakaz wydany przez organ gminy miasta Wrocławia w dniu 6 listopada 2018 roku}

Prezydenta Wrocławia wydał zakaz wobec zgromadzenia „Marsz Polski Niepodległej”, którego zadeklarowanym w zgłoszeniu celem było „Uświęcenie 100 Rocznicy Odzyskania Niepodległości przez Polskę". Podstawą prawną zakazu było prawdopodobieństwo naruszenia przez odbycie planowanego zgromadzenia przepisów art. 14 pkt 1 i 2 ustawy z dnia 24 lipca 2015 roku Prawo o zgromadzeniach, art. 52 ust. 1 k.w. oraz art. 256 i 257 k.k. Prezydent wskazał na podejrzenie udziału w zgromadzeniu osób mających wyroby pirotechniczne lub inne niebezpieczne materiały lub narzędzia, a także fakt, że może dojść do znieważenia osób, nawoływania do nienawiści na tle różnic narodowościowych, etnicznych, rasowych, wyznaniowych ${ }^{69}$.

Podstawą owej decyzji była między innymi analiza zagrożeń przedstawiona przez Komendanta Miejskiego Policji we Wrocławiu, w której wskazał, że uczestnikami siedmiu zgromadzeń realizowanych w latach 2014-2018 przez zgłaszającego były osoby identyfikujące się ze środowiskami skrajnie prawicowymi Młodzież Wszechpolska, ONR, Ruch Wolności oraz pseudokibice WKS Śląsk Wrocław. Podczas zgromadzenia w dniu 4 sierpnia 2018 roku doszło do zagrożenia zdrowia i życia ludzi oraz utraty pokojowego charakteru zgromadzenia, co stało się podstawą do jego rozwiązania ${ }^{70}$. Ponadto organ gminy wskazał, że organizator zgromadzenia brał wielokrotnie czynny udział w zgromadzeniach, których uczestnicy przejawiali postawy ksenofobiczne, o agresywnym nastawieniu do osób o odmiennym światopoglądzie, a przekonania wyrażali w sposób nacechowany agresją werbalną, eksponując hasła, flagi, transparenty zawierające treści, których publiczne propagowanie może wyczerpywać znamiona przestępstw z nienawiści. Podczas tych manifestacji wykorzystywano także zabronione materiały pirotechniczne. Ponadto podczas zgromadzenia środowisk nacjonalistycznych w 2015 roku osoba obecnie zgłaszająca zgromadzenie spaliła kukłę nawiązującą wizerunkiem do żydowskiego mężczyzny, trzymającą flagę Unii Europejskiej, za co została skazana w 2017 z art. 256 k.k. ${ }^{71}$

Organizator złożył odwołanie od decyzji Prezydenta do Sądu Okręgowego we Wrocławiu. Wskazał w nim między innymi, że cel zgromadzenia zgłoszony w zawiadomieniu nie narusza przepisów prawa karnego, a prawo do swobodnego świętowania rocznicy odzyskania przez Polskę niepodległości mają wszyscy mieszkańcy Wrocławia, osoby o różnych poglądach i różnych preferencjach obchodzenia szczególnie wyjątkowej, albowiem setnej rocznicy odzyskania niepodległości ${ }^{72}$.

69 Decyzja Prezydenta Wrocławia z dnia 6 listopada 2018 r., WBZ.DBO.5310.2.42.2018.AB.

70 Ibidem, s. 1-2.

71 Ibidem, s. 2.

72 Postanowienie Sądu Okręgowego we Wrocławiu z dnia 8 listopada 2018 r., I Ns 50/18, LEX nr 2630351, https://sip.lex.pl/orzeczenia-i-pisma-urzedowe/orzeczenia-sadow/i-ns-50-18-postanowie nie-sadu-okregowego-we-wroclawiu-522724047. 
Sąd uznał, że wskazane przez Prezydenta Wrocławia przesłanki szczegółowe zakazu mieszczą się zwłaszcza w pierwszej grupie przesłanek, odnoszą się one do okoliczności pewnych i aktualnych w dniu wydawania decyzji, stąd też sama potencjalność zdarzenia nie jest wystarczająca do wydania zakazu zgromadzenia $^{73}$. W opinii sądu na etapie postępowania wyjaśniającego organ administracji nie wykazał faktów dających podstawę do twierdzenia, że w zgromadzeniu będą brały udział osoby (jako uczestnicy zgromadzenia) mające przy sobie wyroby pirotechniczne lub inne niebezpieczne narzędzia. Natomiast przesłanka - cel zgromadzenia lub jego odbycie naruszają przepisy karne - w obowiązującym stanie prawnym nie znajduje zastosowania jako podstawa zakazu zgromadzenia wobec wadliwości konstrukcji. W tak sformułowanej treści organ gminy musi wskazać dokładny przepis karny, którego hipotezę narusza cel lub odbycie zgromadzenia, natomiast regulacje prawnokarne odnoszą się do osób, nie zaś zdarzeń. Konstrukcja wyklucza więc możliwość naruszania przepisów przez zdarzenie, mogą to bowiem uczynić jedynie osoby odbywające zgromadzenie lub określające jego cel ${ }^{74}$.

Sąd odniósł się jednak do omawianej przesłanki w większym kontekście. Wskazał na doniosłą rolę wolności zgromadzeń w państwie demokratycznym, określił ową wolność jako warunek istnienia społeczeństwa demokratycznego ${ }^{75}$. Każde ograniczenie więc podlega ocenie: czy prowadzi do osiągnięcia celów, czy nie da się ich osiągnąć bez stosowania ograniczeń oraz czy efekty ograniczeń są zbilansowane $\mathrm{z}$ ciężarami nakładanymi na jednostkę ${ }^{76}$. Wprowadzone ograniczenia powinny więc spełniać postulat niezbędności, przydatności i zbilansowania (proporcjonalności sensu stricto). Odnośnie do rozpatrywanej przesłanki cel regulacji da się osiągnąć bez stosowania dodatkowych ograniczeń. Zindywidualizowany uczestnik zgromadzenia czy jego organizator, dopuszczając się określonych czynów, będzie bowiem podlegał karze określonej w kodeksie karnym, a zatem istniejące regulacje $\mathrm{w}$ dostatecznym stopniu wykluczają popełnienie czynów zabronionych określonych $\mathrm{w}$ ich treści ${ }^{77}$. Jeśli zaś czyn zostanie popełniony $\mathrm{w}$ trakcie zgromadzenia, wówczas odpowiednie organy odpowiedzialne za zapewnienie bezpieczeństwa i porządku publicznego (policja, służby specjalne, straż gminna) dokonają zatrzymania. Jest to wówczas odpowiedzialność indywidualna i realna, a nie zbiorowa i hipotetyczna. Zdaniem SO: „klucz do ochrony bezpieczeństwa i porządku leży w efektywności (skuteczności) następczych działań służb odpowiedzialnych za zapewnienie tych wartości, nie zaś w prewencyjnym zakazie określonych zgromadzeń opartym na niejasnych przesłankach"78. Skoro służby

73 Zgodnie $\mathrm{z}$ orzecznictwem niedopuszczalna jest rozszerzająca wykładnia przesłanek wydania zakazu zgromadzenia; wyrok NSA z dnia 25 maja 2006 r., IOSK 329/06, ONSAiWSA 2007, nr 2, poz. 45, s. 9 .

74 Postanowienie Sądu Okręgowego we Wrocławiu z dnia 8 listopada 2018 r., s. 9-10.

75 Ibidem, s. 6.

76 Należy posługiwać się takimi środkami prawnymi, które będą skuteczne w osiągnięciu celów, a przy tym najmniej uciążliwe dla jednostek; ibidem, s. 10-11.

77 Ibidem, s. 11.

78 Ibidem. 
mogą zapewnić realizację celu — niepopełnienia czynów zabronionych — w sposób mniej inwazyjny dla wolności zgromadzeń niż zakaz, to tym samym analizowana przesłanka jest nieproporcjonalna i niekonieczna, a w rezultacie niekonstytucyjna. Ponadto zakaz zgromadzeń wydany na omawianej przesłance stanowi w opinii sądu zabronione przez TK, ,zamrożenie debaty społecznej i wymuszone milczenie o nieujawnionych zjawiskach", nie można bowiem wykluczyć, że ostatecznie uczestnicy zgromadzenia nie popełnią czynów zabronionych ${ }^{79}$.

Sąd odniósł się także do przywołanych w decyzji o zakazie zgromadzenia art. 256 i 257 k.k. Stwierdził, że „hasła obraźliwe i szokujące nie muszą być same w sobie traktowane jako naruszenie pokojowego charakteru zgromadzeń. Chodzi o zagrożenia poważne i bezpośrednie, gdy pojawiają się przemoc lub szkody na mieniu" ${ }^{80}$. W opinii sądu podczas zgromadzeń „prezentujących hasła wyrażające negatywne emocje wobec określonych grup, np. etnicznych czy religijnych nie dochodzi jeszcze do przemocy czy powstania szkód fizycznych, a zagrożenie dla publicznego bezpieczeństwa czy porządku nie jest bezpośrednie, a potencjalne"81. Ponadto zgodnie z wyrokiem TK oraz orzecznictwem ETCP obrażanie grup narodowościowych, etnicznych, rasowych przeprowadzeniem zgromadzenia lub jego celem znajduje się $\mathrm{w}$ zakresie ochrony wolności zgromadzeń ${ }^{82}$. Sąd podkreślił także, że ograniczenie prawa zgromadzeń nie może wynikać z tego, że organy władzy publicznej nie akceptują stanowiska uczestników zgromadzenia, „Władze państwowe powinny w każdych okolicznościach wykazywać odpowiedni poziom tolerancji dla pokojowych zgromadzeń niezależnie od tego, że odbywanie się zgromadzeń może się wiązać się z pewnymi zaburzeniami porządku publicznego" ${ }^{83}$. Sąd podkreślił, że nie jest rolą organów administracji ani sądów analizowanie nienaruszających przepisy obowiązującego prawa, haseł, idei, treści zgromadzenia przez pryzmat własnych przekonań moralnych (osób podejmujących decyzje) bądź przekonań większości społeczeństwa. Zniweczyłoby to konstytucyjną wolność zgromadzeń, naruszając postawy materialnoprawne zakazu ${ }^{84}$. Dlatego sąd nie podzielił wskazanych w decyzji o zakazie zgromadzenia argumentów Prezydenta Miasta Wrocławia i uchylił decyzję zakazującą zgromadzenie.

79 Ibidem.

${ }^{80}$ Powołując się na wyrok TK z 2004 r. (z dnia 10 listopada 2004 r., Kp 1/04, OTK-A 2004, nr 10, poz. 105), sąd podkreślił, że zakaz zgromadzenia lub jego rozwiązanie są dopuszczalne tylko wtedy, gdy zagrożenie dla bezpieczeństwa lub porządku jest bezpośrednie; postanowienie Sądu Okręgowego we Wrocławiu z dnia 8 listopada 2018 r., s. 12.

81 Ibidem.

82 Niezależnie od tego, czy obrażana grupa stanowi mniejszość, czy większość w danej perspektywie.

83 Postanowienie Sądu Okręgowego we Wrocławiu z dnia 8 listopada 2018 r., s. 12-13.

${ }^{84}$ Ibidem, s. 13. 


\section{Zakaz wydany przez organ gminy miasta stołecznego Warszawy w dniu 7 listopada 2018 roku}

Ostatnim przypadkiem poddanym analizie jest zakaz wydany w 2018 roku przez Prezydent Miasta Warszawy wobec zgromadzenia cyklicznego Marsz Niepodległości. Podstawą prawną wskazaną w decyzji o zakazie był art. 14 pkt 2 ustawy z 2015 roku, czyli zagrożenie dla życia lub zdrowia albo mienia w znacznych rozmiarach ${ }^{85}$. Niemniej w uzasadnieniu organ gminy obszernie omówił szerszy kontekst społeczno-polityczny decyzji, wskazując na zagrożenia związane $\mathrm{z}$ mową nienawistną, zakazanymi ideologiami, nacjonalizmem, czyli między innymi przestępstwami wskazanymi w art. 256, 257 k.k. Sąd w orzeczeniu odniósł się zarówno do wskazanej podstawy prawnej, jak i szerszego kontekstu przywołanego przez organ gminy.

Uzasadnieniem wskazanej przesłanki zakazu były między innymi niepokojące, w opinii gminy, działania policji, brak komunikacji między władzami oraz informacje o uczestnictwie grup ekstremistycznych w Marszu Niepodległości. Gmina wskazała, że policja zwróciła się o wprowadzenie dodatkowych zabezpieczeń na trasie planowanego przemarszu zgromadzenia pod kątem ewentualnych zagrożeń terrorystycznych ${ }^{86}$. W ocenie Prezydenta mogło to świadczyć o istnieniu realnego zagrożenia lub o braku funkcjonariuszy, którzy mogliby zabezpieczyć zgromadzenie. Organ gminy wskazał na obawy związane z masową absencją chorobową policjantów oraz problemy we współpracy z Ministrem Spraw Wewnętrznych i Administracji, a także Komendą Stołeczną Policji w zakresie zabezpieczenia uroczystości organizowanych w Warszawie. W decyzji organ gminy wskazał na informacje (pochodzące ze stron internetowych) o zamiarze obecności na Marszu grup skrajnie prawicowych ekstremistów - Siczy Karpackiej oraz szturmowców w ramach Czarnego Bloku, od czego nie odżegnywali się zdaniem gminy organizatorzy Marszu. Organ gminy wskazał, że od roku 2010 podczas wszystkich Marszów Niepodległości dochodziło do poważnych naruszeń bezpieczeństwa i porządku publicznego, a w sytuacji zaistniałej w 2018 roku zdaniem organu gminy nie było możliwości zapewnienia przez policję zabezpieczeń, jakie miały miejsce w latach poprzednich ${ }^{87}$. Brak wsparcia władz państwowych oraz niemożność zapewnienia zasobami organów gminy bezpieczeństwa uczestnikom zgromadzenia oraz mieszkańcom Warszawy legły u podstaw uzasadnienia zakazu.

85 Decyzja Prezydenta Miasta Stołecznego Warszawy z dnia 7 listopada 2018 r., nr WV/5310/ ZG/4/2018.

${ }^{86}$ A także o zwiększoną mobilizację placówek medycznych z oddziałem ratunkowym w Warszawie i wskazywała na możliwość uczestnictwa w marszu środowisk ekstremistycznych, informowała o możliwości wystąpienia znacznego prawdopodobieństwa zagrożenia bezpieczeństwa i porządku publicznego policjantów ze strony manifestantów.

87 Decyzja Prezydenta Miasta Stołecznego Warszawy z dnia 7 listopada 2018 r., s. 7-8. 
Organ gminy wskazał w uzasadnieniu także na szerszy kontekst społeczno-polityczny, w którym została podjęta decyzja o zakazie zgromadzenia. Prezydent Warszawy podkreśliła ogromną wagę święta niepodległości, któremu władze państwowe i samorządowe powinny nadać wyjątkową chwałę i celebrę. Dzień ten determinuje w opinii organu gminy podjęcie działań wyprzedzających i zabezpieczających, aby uroczystości odbywały się godnie, z poszanowaniem praw i wolności obywatelskich. Na podstawie wieloletnich doświadczeń Prezydent wskazała, że uczestnicy Marszów Niepodległości nie chcą przeżywać owego święta w spokoju i refleksji. Przytoczyła przykład marszu z 2017 roku, ,zorganizowanego przez środowiska o skrajnych poglądach nacjonalistycznych, rasistowskich, ksenofobicznych, homofobicznych [...]”, którego uczestnicy naruszali porządek prawny, niosąc symbole i skandując hasła rasistowskie ${ }^{88}$. Część symboli i okrzyków wskazywała jednoznacznie na związek z zakazanymi ideologiami bądź odnosiła się do różnic narodowościowych, rasowych, wyznaniowych. Prezydent przypomniała inne marsze, podczas których uczestnicy ,inaczej niż przyjęto w zwyczaju wyrażali patriotyzm, poczucie wolności obywatelskich, równouprawnienie. Wobec swoich oponentów, stosując często brutalność werbalną i fizyczną"89.

W uzasadnieniu organ gminy powołał się na rezolucję Parlamentu Europejskiego z 25 października 2018 roku w sprawie wzrostu liczby neofaszystowskich aktów przemocy w Europie, wskazując fragmenty omawiające wydarzenia w Polsce, jak demonstracja w Katowicach w 2017 roku — członkowie skrajnie prawicowego ONR zawiesili na symbolicznych szubienicach zdjęcia sześciu posłów do PE, którzy, zgodnie z rezolucją, stanęli w obronie tolerancji i innych wartości europejskich. Jak dotąd, wskazuje gmina, podejrzanym nie postawiono zarzutów mimo licznych materiałów medialnych. Fragmenty rezolucji dotyczyły także wydarzeń podczas Marszu Niepodległości w 2017 roku: Parlament Europejski wskazał, że demonstranci nieśli transparenty z ksenofobicznymi hasłami oraz symbolami faszystowskimi z lat trzydziestych XX wieku. W opinii Prezydent Warszawy Parlament Europejski jest zaniepokojony między innymi: postępującym uznawaniem faszyzmu, rasizmu, ksenofobii i innych form nietolerancji w UE za coś normalnego, zmową przywódców politycznych, partii i organów ścigania z neofaszystami i neonazistami w niektórych państwach członkowskich UE; bezkarnością owych środowisk w niektórych państwach członkowskich, co jest jednym z powodów wzrostu liczby aktów przemocy organizacji skrajnie prawicowych. PE wzywa państwa członkowskie do podjęcia działań w celu zapobiegania przestępstwom z nienawiści, potępiania mowy nienawiści; apeluje do państw członkowskich, by zwalczały organizacje szerzące mowę nienawiści i przemoc w przestrzeni publicznej ${ }^{90}$. Prezydent Warszawy w decyzji zakazującej zgromadzenia Marsz Niepodległości w 2018 roku wskazała także stanowisko Episkopatu Polski

88 Ibidem, s. 4.

89 Ibidem.

90 Ibidem, s.6. 
w dokumencie przyjętym 14 marca 2017 roku, w którym zauważa on pojawienie się w Polsce postaw przeciwstawnych patriotyzmowi. Należy do nich nacjonalizm, który w radykalnych postaciach stanowi antytezę prawdziwego patriotyzmu, usiłuje zmieść różnorodność kulturową, regionalną czy polityczną w jednolitym i uproszczonym schemacie ideologicznym. Cytowany fragment dokumentu przedstawia także apel Episkopatu, aby nie dopuścić do sytuacji, w której skrajny nacjonalizm rodzi nowe formy totalitarnych aberracji, również wówczas, gdy fundamentem nacjonalizmu jest religia, co rodzi fundamentalizmy ${ }^{91}$.

Prezydent podkreśliła, że wolność organizowania i uczestnictwa w zgromadzeniach jest jedną $\mathrm{z}$ podstawowych wolności konstytucyjnych, lecz nie ma charakteru bezwarunkowego. Organy władzy publicznej mają nie tylko zapewnić możliwość korzystania $\mathrm{z}$ owych praw i wolności, lecz także w razie konieczności stosować niezbędne sankcje: „obowiązkiem organów administracji jest zapewnienie każdemu możliwości nieskrępowanej realizacji jego woli w zgodzie $\mathrm{z}$ obowiązującym prawem, a także w razie konieczności wymuszanie od innych podmiotów prawa poszanowania dla tych działań" 92 . W ustroju demokratycznym wszyscy są równi wobec prawa i mają prawo do równego traktowania przez władze publiczne, stąd też „korzystanie przez jednych z ich katalogu praw i wolności nie może powodować ograniczenia czy zagrożenia dla realizacji praw i wolności innych. Żaden podmiot nie może być uprzywilejowany wobec innych"93. Ponieważ zgromadzenia odbywają się w przestrzeni publicznej, toteż prawodawca wprowadził regulacje pozwalające na ograniczenie korzystania z wolności zgromadzeń, jeśli powodowałoby to zagrożenie innych wartości chronionych prawem. Założenie to legło, w opinii organu gminy, u podstaw art. 14 ustawy Prawo o zgromadzeniach z 2015 roku.

Stowarzyszenie „Marsz Niepodległości” odwołało się od decyzji Prezydent do Sądu Okręgowego w Warszawie, w efekcie czego sąd uchylił zaskarżoną decyzję $^{94}$. W orzeczeniu SO podkreślił, że wolność zgromadzeń jest podstawowym prawem wynikającym z Konstytucji RP oraz ratyfikowanych przez Polskę umów międzynarodowych. Jest warunkiem istnienia społeczeństwa demokratycznego, służy oddziaływaniu jednostek na politykę władz państwa przez prezentowanie swoich poglądów, jest przejawem sprawowania demokracji bezpośredniej. Ograniczenie wolności zgromadzeń może nastąpić jedynie w sytuacjach wyjątkowych, należycie uzasadnionych, jej ograniczenia muszą wynikać z ustawy, muszą być niezbędne w społeczeństwie demokratycznym dla ochrony innych konfliktujących się wartości i odpowiadać testowi proporcjonalności ${ }^{95}$. Powołując się na

91 Ibidem, s. 6-7.

92 Ibidem, s. 2.

93 Ibidem.

94 Postanowienie Sądu Okręgowego w Warszawie XXV Wydział Cywilny z dnia 8 listopada 2018 r., XXV Ns 196/18 (niepubl.).

95 Ibidem, s. 4-5. 
orzecznictwo Trybunału Konstytucyjnego, sąd stwierdził, że przesłanki z art. 14 pkt 2 wskazane przez gminę jako podstawa zakazu, muszą mieć miejsce w dniu wydawania decyzji o zakazie, a okoliczności te muszą być bardzo prawdopodobne, oparte na przykład na informacjach od właściwych służb. Do zastosowania art. 14 pkt 2 ustawy wystarczy już sama potencjalność zaistnienia opisanych sytuacji, konieczne jest jednak uprawdopodobnienie tych przesłanek. W ocenie sądu Prezydent miasta stołecznego Warszawy temu obowiązkowi nie sprostała, co stało się powodem uchylenia decyzji o zakazie zgromadzenia. Prezydent, w opinii sądu, „,nie przedstawiła de facto żadnego dokumentu, który potwierdzałby zaistniałe przesłanki zagrożenia życia, zdrowia lub mienia"96. Wydanie decyzji nie było poprzedzone odpowiednimi czynnościami wyjaśniającymi, w tym w szczególności analizą oceny ryzyka przez policję.

Sąd wskazał, że decyzja o zakazie nie może się opierać na przypuszczeniach i spekulacjach oraz wynikać z tego, że organ wydający zakaz nie akceptuje poglądów organizatora marszu ${ }^{97}$. Organ gminy nie wykazał, że Stowarzyszenie „Marsz Niepodległości" zapraszało na marsz ugrupowania głoszące hasła nazistowskie lub banderowskie, a samo Stowarzyszenie odcinało się od tych insynuacji. W opinii sądu za przeciwdziałanie różnym incydentom, które miały miejsce w poprzednich latach, powinna odpowiadać straż marszu lub policja, ich rolą jest eliminowanie różnych grup ekstremistycznych, które mogłyby się przyłączyć do marszu, zakaz zgromadzeń nie jest adekwatnym środkiem w takiej sytuacji. W przypadku naruszenia porządku publicznego organ gminy, policja czy organizatorzy mogą skorzystać z innych środków, w tym rozwiązanie zgromadzenia ${ }^{98}$.

Sąd Apelacyjny w Warszawie utrzymał w mocy wyrok sądu pierwszej instancji i oddalił zażalenie Prezydent Warszawy. W orzeczeniu podkreślił, że „wolność zgromadzeń stanowi warunek i konieczną składową demokracji, a także przesłankę korzystania z innych wolności i praw człowieka [...]. [...] Celem wolności zgromadzeń jest nie tylko zapewnienie autonomii i samorealizacji jednostki, ale również ochrona procesów komunikacji społecznej niezbędnych dla funkcjonowania demokratycznego społeczeństwa" "99. Sąd wskazał na wyjątkowość ograniczeń owej wolności w celu ochrony wartości sprecyzowanych w art. 31 ust. 3 Konstytucji RP, czyli koniecznych w demokratycznym państwie dla jego bezpieczeństwa lub porządku publicznego, ochrony środowiska, zdrowia, moralności publicznej albo wolności i praw innych osób. Przy czym ograniczenia nie mogą

96 Ibidem, s. 5.

97 Sąd podkreślił, że argumentacja dotycząca głoszenia haseł sprzecznych z poglądami wielu Polaków podczas marszu w poprzednim roku, a nawet uznanych za ksenofobiczne i rasistowskie, nie może być podstawą zakazu w oparciu o przesłankę art. 14 pkt 2 - zagrożenia życia lub zdrowia albo mienia. Ponadto sąd podkreślił, że do chwili wydania postanowienia żadne osoby nie zostały skazane za głoszone hasła; ibidem, s. 6-7.

98 Ibidem, s. 7.

99 Ibidem, s. 15. 
naruszać istoty wolności (czyli nie mogą ograniczać owej wolności ponad miarę możliwości korzystania z niej) oraz muszą być proporcjonalne w stosunku do realizacji danego celu ${ }^{100}$. Odwołując się do orzecznictwa Trybunału Konstytucyjnego, sąd podkreślił, że „korzystanie z wolności nie może być reglamentowane przez państwo" ${ }^{101}$, obowiązkiem władz publicznych jest nie tylko usunięcie przeszkód w zakresie korzystania z wolności zgromadzeń i zaniechanie nieuzasadnionej ingerencji, ale także podjęcie kroków w celu realizacji tego prawa, na przykład zapewnienie ochrony grupom organizującym demonstrację. Jednocześnie nie można akceptować głoszenia poglądów prawnie zakazanych, w tym wzywających do nienawiści rasowej czy propagujących ideologię faszystowską. Niemniej sama obawa przyłączenia się do zgromadzenia ekstremistów, osób głoszących takie poglądy może wpływać na ograniczenie prawa wolności zgromadzeń innych osób oraz mogłaby być zachętą do agresywnych działań w sferze publicznej i wpływać na realizację prawa wolności zgromadzeń obywateli. Władza publiczna ma obowiązek ochrony każdego obywatela, który w sposób legalny korzysta ze swego prawa ${ }^{102}$.

Reasumując, przedstawione uzasadnienia decyzji aktorów publicznych pozwalają na wskazanie specyficznych dla danego aktora percepcji, rozumienia wartości i koncepcji istotnych z punktu widzenia instrumentów ochrony demokracji. W wypadku organów gminy (głównie miasta stołecznego Warszawy) jako priorytetowe jawią się wartości takie jak pluralizm, wolność ludzi w realizacji własnej woli (zgodnej z prawem), jednak, co gmina wyraźnie podkreśla, w równym stopniu dla każdego. W rozumieniu gminy równość wszystkich wobec prawa, w tym prawo do równego traktowania przez władze publiczne jest podstawą w zapewnieniu realizacji praw i wolności człowieka, więc granicą wolności jednych obywateli jest wolność i poszanowanie praw innych ludzi. Wolność zgromadzeń jest dla gmin jedną z podstawowych wolności konstytucyjnych, niemniej nie jest ona bezwarunkowa, stąd też zagrożenie dla innych wartości chronionych prawem uprawnia gminy do ograniczenia korzystania z wolności zgromadzeń.

Gminy wskazują, że ich obowiązkiem jako organu władzy publicznej jest zapewnienie wszystkim obywatelom możliwości korzystania z praw i wolności, ale także w razie konieczności stosowanie sankcji w celu wymuszenia od innych podmiotów poszanowania realizacji woli i praw innych ludzi. Służy temu między innymi zwalczanie prześladowań i nietolerancji przez prawną ochronę przed przestępstwami z nienawiści, wyrażoną w artykułach 256 i 257 k.k. Jest to z punktu widzenia gmin istotny element antydyskryminacyjnej polityki państwa demokratycznego oraz instrument zapewnienia porządku publicznego.

100 Postanowienie Sąd Apelacyjny w Warszawie VI Wydział Cywilny z dnia 10 listopada 2018 r., VI Acz 1179/18, s. 14, https://www.hfhr.pl/wp-content/uploads/2019/09/VI-ACz-1179.18postanowienie-z-uzasad..doc.

101 Ibidem, s. 15.

102 Ibidem, s. 15-16. 
Wrogość na tle rasowym, narodowościowym, dyskryminacja, nietolerancja powodują, w rozumieniu organów gmin, poważne napięcia społeczne i tym samym destabilizują porządek publiczny. Odwołując się do obiektywnych autorytetów zewnętrznych i wewnętrznych gminy, podkreślają wagę problematyki radykalizmu prawicowego, nacjonalizmu i płynących zeń zagrożeń społeczeństwa i państwa demokratycznego. Wskazują tu na skutki ideologii totalitarnych lat trzydziestych XX wieku. W przeświadczeniu organów gmin potencjalność przestępstw z nienawiści jest wystarczającym argumentem na ograniczenie wolności zgromadzeń.

Analiza postanowień sądów pozwala stwierdzić, iż instytucje te stoją jednoznacznie na pozycjach wolnościowych - priorytetową wartością, którą należy chronić, jest wolność jednostki, w tym wolność zgromadzeń, będąca warunkiem istnienia społeczeństwa i państwa demokratycznego i przesłanką korzystania $\mathrm{z}$ innych wolności i praw człowieka, w tym wolności słowa. Zgodnie ze stanowiskiem sądów obowiązkiem władz publicznych jest ochrona każdego obywatela, który w sposób legalny korzysta z wolności, oraz zapewnienie możliwości ich realizacji. Ingerencja władz publicznych w sferę wolności i praw człowieka może mieć więc charakter tylko wyjątkowy.

Sądy są zgodne, że granicą wolności zgromadzeń jest bezpośrednie zagrożenie życia, zdrowia ludzi lub mienia w znacznych rozmiarach, a więc zagrożenia poważne i bezpośrednie, gdy pojawia się przemoc. Do takich zagrożeń sądy nie zaliczają obraźliwych haseł. Negatywne emocje wobec określonych grup społecznych wyrażane podczas zgromadzeń mają charakter zagrożenia potencjalnego i znajdują się tym samym w zakresie ochrony wolności zgromadzeń. Sądy przyznają więc prymat wolności zgromadzeń oraz debacie publicznej w zderzeniu z potencjalnymi zagrożeniami wynikającymi z wyrażania treści nienawistnych. Władze publiczne powinny cechować się tolerancją wobec pokojowych zgromadzeń i mają obowiązek zachować neutralność światopoglądową. Sąd Apelacyjny w Warszawie podkreślił jednocześnie, że nie można akceptować głoszenia poglądów prawnie zakazanych, w tym rasistowskich i propagujących faszyzm, niemniej jednak wówczas reakcje powinny być proporcjonalne i uzasadnione, tak aby nie naruszały istoty samej wolności zgromadzeń realizowanych przez innych ludzi.

\section{Wnioski}

Od początku XX wieku problematyka ochrony demokracji jest niezmiennie przedmiotem zainteresowań teoretyków oraz praktyków życia politycznego w demokracjach konstytucyjnych. Jak dotąd państwa nie znalazły uniwersalnego modelu ochrony systemu demokratycznego przed jego wrogami, a przyjęte rozwiązania są efektem różnorodnych czynników, w tym doświadczeń historycznych społeczeństw. Celem artykułu było wskazanie, jak w Polsce, państwie 
o doświadczeniach totalitarnych i tradycjach wolnościowych, ukształtowany został $\mathrm{w}$ prawie i praktyce jeden $\mathrm{z}$ instrumentów ochrony demokracji, jakim jest zakaz zgromadzeń. W odniesieniu do dyskusji teoretycznej celem było wskazanie, któremu modelowi ochrony demokracji bliższe są rozwiązania przyjęte w Polsce w badanym aspekcie — demokracji walczącej czy proceduralnej, a także przybliżenie odpowiedzi na pytanie, co mogło być motywacją do przyjęcia takich, a nie innych rozwiązań. Artykuł przyjął jedną z wielu możliwych perspektyw analizy czynników wpływających na decyzje aktorów publicznych w zakresie tworzenia polityki ochrony demokracji, a mianowicie perspektywę ideową. Podstawą analizy były wybrane przypadki zakazów zgromadzeń organizowanych przez środowiska skrajnie prawicowe w Polsce, które szczególnie od drugiej dekady XXI wieku wzbudzają zainteresowanie i kontrowersje wśród opinii publicznej i decydentów publicznych.

Przeprowadzona analiza wskazała, że przyjęte w Polsce unormowania prawne zakazu zgromadzeń, w ustawach Prawo o zgromadzeniach z 1990 oraz 2015 roku, umożliwiają zastosowanie zakazu zgromadzeń zgodnie z założeniami koncepcji demokracji walczącej, albowiem stwarzają możliwość zapobiegawczego (prewencyjnego) i represyjnego reagowania wobec 'wrogów demokracji' działających pokojowo. Wynika to z szerokiego zakresu przesłanek zakazu, obejmującego nie tylko utratę pokojowego charakteru zgromadzeń, zagrożeń zdrowia, życia i mienia, lecz także naruszenie przepisów karnych przez cel lub odbycie zgromadzenia $^{103}$.

Praktyka pokazała jednak, że aktorzy publiczni, którzy zgodnie z ustawami mają kompetencje do decydowania w zakresie odbywania zgromadzeń, przyjmują odmienne stanowiska co do sposobu implementacji zakazu. Gminy dopuszczają prewencyjny zakaz zgromadzeń $\mathrm{w}$ związku z naruszeniem wolności słowa jako instrument zapewniający porządek publiczny, którego podstawą jest pluralizm, poszanowanie praw i wolności innych ludzi oraz równość wobec prawa. Stanowisko gmin jest tym samym bliskie modelowi demokracji walczącej, która nie zachowuje neutralności względem poglądów prezentowanych przez uczestników dyskursu publicznego.

Sądy natomiast stoją na stanowisku, że przedmiot zgromadzeń nie może być podstawą prewencyjnego ich ograniczenia, albowiem wolność zgromadzeń jest warunkiem istnienia społeczeństw demokratycznych. W opinii polskich sądów przesłanką zakazu jest przemoc, bezpośrednie zagrożenie życia, zdrowia i mienia. Ograniczają tym samym wyraźnie możliwość zakazu zgromadzeń pokojowych. Zgodnie z argumentacją krytyków demokracji walczącej sądy wskazują, że prewencyjne ograniczenie zgromadzeń ze względu na przesłankę — cel lub odbycie zgromadzenia naruszają przepisy karne — nie jest środkiem adekwatnym

103 Orzecznictwo wskazuje jednak, że ze względu na wadliwość konstrukcji prawnej przesłanki, sprzeczność celów i odbycia zgromadzenia z prawem karnym nie znajduje zastosowania w polskim prawie jako podstawa zakazu, zob. S. Gajewski, A. Jakubowski, op. cit., s. 99-101. 
i koniecznym, jest on nieproporcjonalny, a więc niekonstytucyjny. Podobne stanowisko przyjął Wojewoda Mazowiecki, który zanegował treści i poglądy jako możliwą przesłankę zakazu zgromadzeń. Szeroka ochrona wolności zgromadzeń przyjęta przez sądy bliższa jest tym samym proceduralnemu modelowi ochrony demokracji. Sądy kładą więc nacisk na działania następcze, odpowiedzialność indywidualną tudzież rozwiązanie zgromadzenia jako efektywne zapewnienie bezpieczeństwa i porządku publicznego. Takie podejście znajduje uzasadnienie także ze względu na wadliwość konstrukcji prawnej omawianej przesłanki.

Analiza wykazała, że różnice w podejściu do ochrony demokracji z jednej strony gmin, a $\mathrm{z}$ drugiej sądów i (w ograniczonym zakresie) wojewodów mogą wynikać między innymi z innej wagi przypisywanej przez aktorów publicznych poszczególnym wartościom demokratycznym. Dla gminy priorytetowe jest zapewnienie pluralizmu oraz równość wszystkich ludzi wobec prawa, rozumiana jako równa możliwość realizacji praw i wolności, dla sądów jest to zapewnienie realizacji wolności jednostki, w tym wolności zgromadzeń jako przesłanki korzystania z innych wolności i praw człowieka. Gminy i sądy odmiennie postrzegają zagrożenia społeczeństwa i państwa demokratycznego. Dla gmin zagrożeniem jest dyskryminacja, nietolerancja, nieposzanowanie woli innych ludzi przez między innymi mowę nienawiści. Sądy jako największe zagrożenie postrzegają narzędzia represyjne, ograniczające podstawowe wolności w demokracjach liberalnych. Rolą organów władzy jest więc według sądów zagwarantowanie w jak największym stopniu wolności zgromadzeń, natomiast dla gmin jest zapewnienie realizacji praw i wolności dla wszystkich. Skutkuje to różnicami w definiowaniu granicy wolności i tolerancji. Dla gmin są nimi poszanowanie praw i wolności innych ludzi (brak zagrożeń w ich realizacji), dla sądów są to bezpośrednie zagrożenie życia i zdrowia ludzi.

Przyjęta przez sądy wykładnia przesłanek zakazu zgromadzeń i wadliwe przepisy prawa wykluczają możliwość prewencyjnego ograniczenia pokojowych zgromadzeń w Polsce na podstawie naruszenia przepisów karnych przez cele lub odbycie zgromadzenia. Wymusiło to na gminach zmianę strategii reagowania - z instrumentów prewencyjnych na działania post factum. Gminy wskazuja obecnie na konieczność efektywnego reagowania na wszelkie przejawy łamania prawa podczas zgromadzeń, w tym przestępstw związanych z mową nienawiści. 


\section{Bibliografia}

Accetti I.C., Zuckerman I., What's wrong with militant democracy?, „Political Studies” 65 (IS), 2017.

Backes U., Limits of political freedom in democratic constitutional states - A comparative study of Germany, France and USA, „Totalitarismus und Demokratie” 3, 2006.

Belavusau U., Hate speech and constitutional democracy in Eastern Europe: Transitional and militant? (Czech Republic, Hungary and Poland), „Izraeli Law Review” 47, 2014, nr 1.

Bleich E., Race Politics in Britain and France. Ideas and Policymaking since the 1960s, Cambridge 2003.

Bodnar A., Shaping the freedom of asembly: Counter-productive effects of the Polish road towards illiberal democracy, [w:] Free to Protest: Constituent Power and Street Demonstration, red. A. Sajo, Utrecht 2009.

Bourne A., Beyond Militant Democracy: Mapping Initiatives Opposing Populist Parties, manuskrypt 2021.

Bourne A., The Proscription of parties and the problem with militant democracy, „The Journal of Comparative Law" 7, 2012, nr 1.

Brems E., State regulation of xenofobia versus individual freedoms: The European view, „Journal of Human Rights" 1, 2002, nr 4.

Capoccia G., Defending Democracy. Reactions to Extremism in Interwar Europe, Baltimore 2005.

Capoccia G., Militant democracy: The institutional bases of democratic self-preservation, „Annual Review of Law and Social Science" 9, 2013.

Donselaar J. van, Patterns of response to the extreme right in Western Europe, [w:] Right-Wing Extremism in the Twenty-First Century, red. P.H. Merkl, L. Weinberg, London 2003.

Downs W.M., Political Extremism in Democracies. Combating Intolerance, New York 2012.

Flümann G., Streitbare Demokratie in Deutschland und den Vereinigten Staaten. Der staatliche Umgang mit nichtgewalttätigem politischem Extremismus im Vergleich, Wiesbaden 2015.

Fox G.H., Nolte G., Intolerant democracies, „Harvard International Law Journal” 36, 1995, nr 1.

Gajewski S., Jakubowski A., Prawo o zgromadzeniach. Komentarz, Warszawa 2017.

Jaschke H.G., Streitbare Demokratie und Innere Sicherheit. Grundlagen, Praxis und Kritik, Opladen 1991.

Krippendorff K., Content Analysis, Los Angeles 2013.

Kelsen H., Verteigigung der Demokratie, [w:] H. Kelsen, Verteidigung der Demokratie. Abhandlungen zur Demokratietheorie, wyb. i red. M. Jestaedt, O. Lepsius, Tübingen 2006.

Kirshner A., A Theory of Militant Democracy. The Ethics of Combating Extremism, New Haven 2014.

Laumond B., State Responses to the Radical Right in France and Germany: Public Actors, Policy Frames and Decision-Making, London 2020.

Löwenstein K., Militant Democracy and fundamental rights, II, „The American Political Science Review" 31, 1937, nr 4.

Malkopoulou A., Introduction. Militant democracy and its critics, [w:] Militant Democracy and Its Critics. Populism, Parties, Extremism, red. A. Malkopoulou, A.S. Kirshner, Edinburgh 2019.

Malkopoulou A., Norman L., Three models of democratic self-defence: Militant democracy and its alternatives, „Political Studies” 66, 2018, nr 2.

The 'Militant Democracy' Principle in Modern Democracies, red. M. Thiel, London 2009.

Müller J.W., Militant democracy, [w:] The Oxford Handbook of Comparative Constitutional Law, red. M. Rosenfeld, A. Sajo, Oxford 2012.

Pfersmann O., Shaping militant democracy, [w:] Militant Democracy, red. A. Sajó, Utrecht 2004. Popper K., Offene Gesellschaft und ihre Feinde, t. 1. Der Zauber Platons, Tübingen 1992.

Rijpkema B., Militant Democracy. The Limits of Democratic Tolerance, New York 2018. 
Rummens S., Abts K., Defending democracy: The concentric containment of political extremism, „Political Studies” 58, 2008, nr 4.

Rzetecka-Gil A., Prawo o zgromadzeniach. Komentarz, LEX 2019.

Tyulkina S., Militant Democracy. Undemocratic Political Parties and Beyond, London-New York 2015.

Wolność zgromadzeń w Polsce w latach 2016-2018. Raport Rzecznika Praw Obywatelskich, Warszawa 2017.

Decyzja Prezydenta Miasta Stołecznego Warszawy z dnia 8 września 2015 r. nr WV/5310/ZG/8/ 2015.

Decyzja Prezydenta Miasta Stołecznego Warszawy z dnia 7 listopada 2018 r. nr WV/5310/ZG/4/ 2018.

Decyzja Prezydenta Wrocławia z dnia 6 listopada 2018 r. nr WBZ.DBO.5310.2.42.2018.AB.

Decyzja Wojewody Mazowieckiego z dnia 10 września 2015 r. nr WBZK-I.6110.22.2015.

Druk sejmowy Sejmu VI kadencji, nr 1288.

Konstytucja Rzeczypospolitej Polskiej z dnia 2 kwietnia 1997 r., Dz.U. 1997 nr 78, poz. 483 z późn. zm. https://isap.sejm.gov.pl/isap.nsf/download.xsp/WDU19970780483/U/D19970483Lj.pdf.

Ustawa z dnia 5 lipca 1990 r. Prawo o zgromadzeniach, http://prawo.sejm.gov.pl/isap.nsf/download. xsp/WDU19900510297/U/D19900297Lj.pdf.

Ustawa z dnia 6 czerwca 1997 r. — Kodeks karny, http://prawo.sejm.gov.pl/isap.nsf/download.xsp/ WDU19970880553/U/D19970553Lj.pdf.

Ustawa z dnia 24 lipca 2015 r. Prawo o zgromadzeniach, http://prawo.sejm.gov.pl/isap.nsf/download.xsp/WDU20150001485/U/D20151485Lj.pdf.

Postanowienie Sądu Apelacyjnego w Warszawie VI Wydział Cywilny z dnia 10 listopada 2018 r., VI Acz 1179/18, https://isap.sejm.gov.pl/isap.nsf/download.xsp/WDU19970780483/U/D1997 0483Lj.pdf.

Postanowienie Sądu Okręgowego w Warszawie XXV Wydział Cywilny z dnia 8 listopada 2018 r., XXV Ns 196/18 (niepubl.).

Postanowienie Sądu Okręgowego we Wrocławiu z dnia 8 listopada 2018 r., I Ns 50/18 LEX nr 2630351, https://sip.lex.pl/orzeczenia-i-pisma-urzedowe/orzeczenia-sadow/i-ns-50-18-postanowie nie-sadu-okregowego-we-wroclawiu-522724047.

Wyrok NSA z dnia 25 maja 2006 r., IOSK 329/06, ONSAiWSA 2007, nr 2, poz. 45.

Wyrok TK z dnia 10 listopada 2004 r., Kp 1/04, OTK-A 2004, nr 10, poz. 105. 